\title{
Land, Place and Resistance to Displacement in Phulbari
}

\section{Sadid Nuremowla}

\section{(2) OpenEdition}

\section{Journals}

\section{Electronic version}

URL: http://journals.openedition.org/samaj/4113

DOI: 10.4000/samaj.4113

ISSN: $1960-6060$

\section{Publisher}

Association pour la recherche sur l'Asie du Sud (ARAS)

\section{Electronic reference}

Sadid Nuremowla, «Land, Place and Resistance to Displacement in Phulbari », South Asia Multidisciplinary Academic Journal [Online], 13 | 2016, Online since 08 March 2016, connection on 19 April 2019. URL : http://journals.openedition.org/samaj/4113 ; DOI : 10.4000/samaj.4113

This text was automatically generated on 19 April 2019

\section{(c) (i) $\odot$}

This work is licensed under a Creative Commons Attribution-NonCommercial-NoDerivatives 4.0 International License. 


\title{
Land, Place and Resistance to Displacement in Phulbari
}

\author{
Sadid Nuremowla
}

\section{AUTHOR'S NOTE}

This article results from my doctoral research which was part of a larger research project on Mining, Livelihoods and Social Network in Bangladesh led by Professor Katy Gardner at the University of Sussex funded by the ESRC/DFID joint research scheme. The author is grateful to the ESRC/DFID for the funding that made the research possible and to Professor Gardner and Professor James Fairhead who supervised my research with great enthusiasm.

\section{Introduction}

1 On the 26 August 2006, five people died and many others were injured when security forces ${ }^{1}$ reportedly opened fire on some 50,000 people gathered in a small town in Phulbari, a sub-district of Dinajpur in north-western Bangladesh. The gathering was a protest in response to a proposal by Asia Energy, a UK-based mining company, to engage in open-pit coal mining. In 1998 The Asia Energy Corporation (Bangladesh) Pty, a whollyowned subsidiary of Global Coal Management Resources plc. (GCM), ${ }^{2}$ was awarded a contract by the Government of Bangladesh to mine coal in Phulbari. The Phulbari coal mine is an open-pit coal mining project which involves digging huge pits with heavy machinery to access the coal deposit. In Phulbari, this method would require removing people from their homes and farm lands. Estimates of the number of people that would be affected by the project vary from 40,000 to 470,000 . Following the protest, the Government suspended the field activities of Asia Energy to review the details of the mining deal. The Government did not, however, cancel the mining contract, and Asia Energy continues to lobby through different channels to resume mining while community 
mobilisation against the mining project persisted. The protest was one of the largest against land dispossession in Bangladesh in recent times, and set an example for the kind of response that initiatives of displacing people from their land were facing (Gardner 2012, Levien 2011, Padel \& Das 2010).

2 An estimation of the economic loss the country would be likely to incur from the mining deal and the environmental threat to rivers and the water supply to Phulbari were stressed in the messages of the protests. The national activist group (the National Committee), based in the country capital of Dhaka, who are mainly left-aligned political activists, intellectuals and sympathetic professionals, use these messages to create a general 'anti-mining' position. The National Committee's (NC) political project is publicized in documents and leaflets where national interest is emphasized, as illustrated by the following points found in a NC leaflet: ' 1 . No to foreign company. 2 . No to coal export. 3. Yes to the extraction of coal by a state-owned body for the best interest of the nation. 4. No to open-pit coal mining. ${ }^{3}$ My long-term participant observation in a village in Phulbari later revealed that people's position regarding the mining was not always consistent with that of the NC. The 'anti-mining' position of the villagers referred to antimining in any form, regardless of method and ownership, foreign or national.

3 The protest has so far been successful in forcing a halt to the mining project. The events of August 2006 in Phulbari town show that the protest was dependent upon the participation of people whose homes and livelihoods were directly threatened by the mine. However, my fieldwork revealed that the stories that characterise local resistance to land loss involve more complex realities and situated practices than the national protest movement acknowledged. The paper presents evidence and stories that show the multi-dimensional nature of land and the relationships that surround it within my fieldsite, issues that remained far outside the public space of protest.

4 The threat of the destruction of land and displacement of local people by the mining project has been a rallying point in public protests. The question is: To what extent does the threat of changes to land and displacements have implications for social relations in the proposed mining sites? Filer (1990), using the case of Panguna mine in the later part of the 1980s, shows that the destruction of waterways, and the making of huge holes in the middle of a community's territory, deeply impacted the local sense of self and community. In addition, the relationship between the changes in landscape and changes in lifestyles and identities is evident in the testimony of the Panguna landowners.

5 Perreault and Valdivia (2010), through a comparative analysis of Ecuadorian and Bolivian resource politics, show how these cases of social movements against the natural resource governance should not be read as yet another case of locals struggling against global structures. Rather, these movements are linked to what is seen as the interests of the population and are aligned with how the resource policies give meaning to development and the nation. Perreault and Valdivia argue that as the ideas about the nation and development may take various trajectories, so may people's position on and connection to issues around natural resources. The paper argues for a perspective which would explain people's connection to resistance to dispossession by going beyond a fixed notion of struggle and taking into account the meaning that the people give to their land place and home.

6 Stuart Kirsch (2006), in his book Reverse Anthropology, examines environmental and social relations among the Yanggom, an ethno-linguistic group in south-central New Guinea. 
Kirsch shows how the Yanggom people's analysis of the environmental impact of the ok Tedi mine offers 'alternative perspectives that take social relations into account' (Kirsch 2006: 129). This perspective can capture the claims and accusations that derive from the individual's vulnerability, which, as Kirsch observes, increases the recognition of the mining company's responsibility for the community. This, in turn, translates into political mobilisation through the formation of social solidarity between the people affected by the mine. In this sense political mobilisation is related to 'specific consequences for persons and social relations' (Kirsch 2006: 222). Following these examples, this paper presents evidence of how local opposition to the threat of displacement and land appropriation relates to the core aspects of life such as safety and survival as well as to the very production of sociality, dignity and personhood. It presents stories of how these aspects conflict with official regimes of land and property.

What follows is based on my doctoral research, which involved a nine-month study of Borogram, a village located in the proposed mining site of Phulbari in the north-western district of Dinajpur, Bangladesh. My research in the village was carried out in keeping with the ethnographic tradition of longer-term dwelling in a 'community'. I conducted participant observation to explore the specificities and realities that shaped the resistance to the proposed mine. The ethnographic materials presented here are derived from interactions and interviews with the village people. I also conducted 20 informal interviews and collected ten oral histories from the protest activists.

The first section of the paper shows how the history of settlement and forest clearance has created a strong sense of ownership via physical labouring and customary rights over land. The second section elaborates on people's own analysis that they use to rationalize their possession and rights to the land. I then move to stories of land dispossession in nearby villages, which produce acute anxieties for the people of Borogram, especially since their land is not even Kagojer land, land owned by those with a formal ownership document, making the prospects facing them even more bleak. I show how Borogram people's shared history of displacement adds to these worries and drives their claims to the land.

\section{Land in Borogram: customary rights via clearance and labouring}

Borogram is located approximately five kilometres from the town centre of Phulbari subdistrict. The total population of Borogram lives in over 500 different households. According to documents from the Phulbari Coal Mine Project, published by Asia Energy, it is projected that over the 35-year lifetime of the mine it will gradually span over 5,933 hectares of land, roughly 60 square kilometres. Along with parts of Phulbari Town, the total area of Borogram Village is to be acquired during the initial stages of the project, as this is where the first part of coal extraction activities are planned (Asia Energy 2008a). The total land acquired is to be used for two activities: one, the removal of soil of up to 270 meters in order to make pits for the extraction of coal, and two, building of associated establishments for dumping coal and constructing offices, employee quarters and roads. According to the project plans and mine maps presented in the Company's project publications, most of Borogram and the surrounding areas are planned sites for digging pits and dumping coal (Asia Energy 2008b). 
10 The establishment of Borogram village took place after the migration from a few neighbouring areas in the district of Chapainawabganj in Northern Bangladesh. According to some of my informants a group of approximately 20 people, forced by repeated river erosion and consequent land loss, first migrated to the flat forest area around Phulbari Rail Station in 1968.

11 The first group of migrants found a flat forest area in the vicinity of Phulbari Township that promised to be fertile for agricultural activities. The forest was gradually cleared into plots where crops could be produced and cattle raised. These initial efforts to clear the forest were hindered by interventions from forest officials, as, according to state laws, destruction of such lands was illegal. On several occasions arrest warrants were issued against male members of the group on charges of illegal destruction of natural forest, but the village continued to grow through the migration of families, landless relatives and neighbours. In turn, a large area was gradually cleared to accommodate a population that now exceeds 2500 individuals living in approximately 500 houses. The area has a literacy rate of $45.06 \%$ with agriculture as the main source of income (BBS 2001). Over the last four decades the people have asserted their rights to the land through their presence, despite legal action from the forest authority supported by the Government. The first group's initial success in securing land by clearing the forest attracted more people from the river-erosion affected areas to migrate to this 'new place'.

Having located an area of flat forest-land in a relatively higher area meant that residents of Borogram needed to develop the means for large quantities of irrigation. Underground water levels remain low in the village, making irrigation through a petroleum-run shallow-tube well difficult, particularly during the dry season. These difficulties with irrigation resulted in an increased popularity of crops that require less water, such as corn. Lower lands are preferred for rice production where shallow-tube wells can be set in a hollow in the ground to reach the water level throughout the production season. Irrigation machines are owned by those villagers who have invested money in setting up mechanisms to meet their own irrigation needs and who simultaneously earn rental income by providing water to other land. Machine owners and their clients are engaged in longer-term seasonal deals based on trust and the faith that both will do their part. Rental fees are usually paid after crops are harvested, and a good harvest is contingent on regular and adequate irrigation service from the machine owners. The longer-term relations of trust, among many others, between these two groups feature in the dynamics of Borogram community.

\section{Land rights and access in Borogram}

13 There are two main types of land in Borogram, popularly categorized as Kagojer jomi and Khas jomi. The meanings of these terms are varied, according to context. In 'local' terms, Kagojer jomi refers to land whose owner has a deed in their possession, while Khas jomi are those lands possessed without an ownership document; in this case ownership is established by the value of efforts put into the land over the years to transform it from a forest to cultivable land. The local terms Kagojer jomi and an insider's assertion of Khas jomi become much more complicated as the village embarks on the protest against mining. Contestation between the rights that the village people have established over the land and the possibility that these rights may be denied by the State's legal system or the 
Company's compensation mechanism plays a significant role in the spread of the protest in Borogram village.

In Bangladesh, Khas land generally connotes government-owned land. This also applies to common bodies of water, such as rivers. The Ministry of Land has the authority to manage these lands as per state legislation. During the 1980s, the Bangladeshi government recognised that Khas land was to be used by the poor, and declared that people who were landless and affected by flooding and river erosion had the right to be allocated Khas land. The Land Reforms Action Programme of 1987 is one such example where landless people's right to be allocated Khas land was prioritized.

These initiatives created a public discourse that supported the relocation of people affected by river erosions, and/or landless people to Khas land. In fact, there were some government projects in Phulbari sub-district where landless people were resettled in the area and provided with Khas land and tiner ghor (a house built with corrugated tin). This public discourse of Khas land therefore created an expectation that landless and displaced people could relocate to unoccupied or 'empty' land, as this was assumed to be khas land. For the original settlers of Borogram the availability of forest land, which they perceived as Khas Land, attracted them to the Phulbari area. One of the elderly villagers who was part of the group that first migrated to Borogram states:

The Government has given Phulbari land to other landless people. Why can't we live on the government's forest land? River erosions made us landless. Why is the government's land left idle and we can't use it? Lots of other people from our home district have moved to Dinajpur area and they are living in the government land. We have heard that government gives away Khas land to the poor. So why can't we get land? (Field notes, 15 May, 2009).

Challenging the idea of keeping forest-land in the hands of the forest department when it could be used for food, this gentleman continues, 'The corrupt forest officials eat up all the benefits that the country could get from this forest land. They collaborate with local wood thieves and sell all the trees, and they lease out the forest land in breach of the law and destroy the forests anyway' (Field notes, 15 May, 2009).

He then rationalizes the villagers' possession and rights to the land:

During our initial migration forest officials threatened to sue us. One day I told a forest officer who came to visit the area that we were producing crops for the country in this infertile land. I told him that if he could prove that the government earned more from this forest than what we were producing we would leave this land. The officer couldn't answer me (Field notes, 15 May, 2009).

The long and arduous efforts put into clearing the land by people who have turned this apparently uncultivable area into cultivable fields adds to their assertion of their rights over it:

I proposed to my neighbours that I knew a place where we could find land to live. Initially I brought 20 to 25 people in Borogram to clear forests for building houses and for agriculture. Some of them went back as they found it very hard to clear forests and prepare it for agriculture. It was tough because the land was high and hard and needed a lot of irrigation. At that time there were no irrigation machines. We all worked very hard for some years on each piece of land that you see are so fertile today. No one thought of cultivating here until we came and worked so hard. It is no longer the government's forest land; it is now our agricultural land ${ }^{4}$ (Field notes, 30 May, 2009).

19 The suffering and harassment faced by the elderly villagers to protect their land during the initial period of establishment enhances their claim over it. Dewani continued: 
Look, there were hardly any nights we could sleep without fear of police in the early days of the village. Forest officials sued us and filed cases against a number of village people. I, along with many others, was arrested and harassed. I spent more than one year in the prison. We suffered but we didn't leave this land. The land you see today didn't come to us easy (Field notes, 30 May, 2009).

These testimonies describe the ways in which people assert their rights over an area of land, making it their own, even though it was originally government land. However, even if there has been long standing local acknowledgement of ownership, based on the histories of hard physical labour, the mine threatens to take all this away. Indeed, their relatively secure land possession has now become volatile and 'insecure' (Jansen 1986: 227) because of the possibility of displacement by the mining company. Let us turn to the second type of land ownership: Kagojer jomi.

21 'Kagojer jomi' also has various ownership patterns. Generally the term 'Kagojer jomi', or 'documented land', is used to indicate land that was not acquired by clearing the forest and whose ownership was documented. A stronger sense of ownership rights over these types of land is asserted as these lands are either bought from previous owners or made socially 'legal'. The process that makes land 'Kagojer jomi' is attached to the means and ways the lands are transferred, sold and exchanged, and the ways that the new ownership is legitimized in the village. Several forms of land transfer processes are practiced in Borogram, none of which necessarily involve the official land transfer processes of the State. Regardless of ownership history, a land becomes 'Kagojer jomi' if the seller and the buyer sign a paper that indicates the selling terms and price. The presence of witnesses during the deal makes it stronger in the face of any possible disputes, which are usually dealt with in the village Bichar, an informal village court. The 'legality' of ownership is defined by the socially-legitimate rights of an individual owner of the land in line with factors such as inheritance. Land owned by a neighbouring villager that has a socially accepted history of official ownership is often not challenged by the new buyers. It is common practice in the village to transfer land ownership with verbal and/or written terms set between the buyers and the sellers, where the Bichar guards the deals and settles the cases of disputes. New buyers carry a particular plot's socially-established history of legality. The land is, thus, always called 'Kagojer jomi', regardless of the number of times the ownership has changed. This notion of land ownership builds on the internalities of long-standing land relations, which are, people believe, beyond the scope of the official procedures of identifying a landowner for any possible compensation. 'I bought this land with my hard earned money. Everyone knows it. But how will I prove it to the officers? I never went to the land office. ${ }^{5}$ (Field Notes, October 23, 2009) As the next section shows, these anxieties are exacerbated by stories that circulate at the village market concerning the fate of people from neighbouring villages whose land was taken by mines.

\section{Stories of dispossession}

The Borogram evening market serves as a meeting point for people from different social categories and a platform for sharing the latest news, including discussions about the mining deal between the Company and the government and information about protest activities. I became a regular participant in these activities during my stay in the village, in part due to the importance of this place for my research, and partly for the same reasons as some others, to charge my mobile phone and laptop. This social setting of 
Borogram village market acts as a forum for forming shared ideas of 'particular patterns' (Gardner 1995: 21).

The stories of land and compensation issues in an on-going coal mine in Baropukuria, a neighbouring coal mining area, are examples of this. The Boropukuria coal mine is located in Chowhati village under Parbatiur sub-district in Dinajpur district of Bangladesh and is about six kilometres from Borogram village, and roughly five kilometres from Phulbari town centre. Boropukuria coal mine is an underground coal mine, where coal is extracted from underground without displacing surface soils. It is fully owned by a state-owned company and operated by Chinese contractors. The coal was first discovered in 1985 and the operation started in 1998. The development of the mine affected the land and livelihood of the local people and their stories and miseries are regularly discussed at the evening market in Borogram. One such story is that of Nasimon Khatun which I present in the next section. I have collected the story through repeated discussions, interviews, and informal chats with Nasimon and her family, as well as other village members.

\section{Story of Nasimon Khatun}

Nasimon Khatun lived with her husband and children in an area where the offices and other structures of Boropukuria coal mine were constructed. Her husband owned enough agricultural land in the present mine office complex to meet their expenditure and save money for the future by selling crops. Overall, Nasimon's family was considered by the village to be well off.

One day a survey group came to Nasimon's house and took some information about their land and assets, and promised that the family would be given good compensation if the mine company had to take their land. They believed them. Meanwhile, Mrs. Nasimon's husband died of an illness before the mine was established leaving her with the seven children. Then, one day, after some time had passed, a group of labourers from the mine arrived at her home and, in the presence of police, started to cut trees from their land. They were told that the company had acquired the land and they would be given proper compensation following the official procedures. The police took Nasimon and her eldest son to the police station where Nasimon denied giving permission for the company people to clear that piece of land. Nasimon and her son were released the next day under the promise that they would not try to hinder the process of land acquisition. They were assured that the government would pay proper compensation for all the land to be acquired. After this incident they didn't try to stop the acquisition of land for fear of getting taken away by the police. A few months later they had to leave their house and all of their land and move to a small piece of land in the village owned by one of their relatives. Because they didn't have space to keep and raise their cows, goats, chickens, and ducks in the new land, they had to sell their animals.

Then began the 'official' process of getting compensation, which neither Nasimon nor her illiterate sons were familiar with. Nasimon couldn't read or write and never went to the district town where the land office, which was responsible for settling land compensation issues, was located. It was no different for her sons. Soon after they were displaced, a high-up official from the district administration office came to the village and asked for a bribe with a promise of giving proper compensation quickly. Nasimon was living on her tiny savings that her husband had left and didn't have money to bribe the officer. After this, her eldest son with a few other affected villagers went to the district land office to claim their compensation. There, they were asked for a 500 taka ( $£ 5$ ) bribe in order to get the list of documents required to submit a compensation application; this was on top of the 200 taka ( $£ 2$ ) they had incurred to get there. In this one visit half of the family's 
total monthly grocery expenditure was gone. It was only the first of many visits that her son had to make for settling compensation matters. Nasimon and her son. When Nasimon's husband originally acquired the land, it was equally divided verbally by him and his brother after the death of their father without making any legal documents, a normal practice in the village. The land office requested proof that Nasimon was actually the wife of the landowner in addition to a recommendation from an elected representative of the local government, the Union Chairman, to prove it. Further complicating matters, they required that Nasimon's husband's brother be present in front of the land officer to prove land ownership. These are some of the complexities that kept arising while they were trying to get their compensation, without much success. The land office was settling the case by the official land holding numbers where Nasimon's lands, according to formal documents, were dispersed and recorded in several holding numbers. Thus, each full procedure had to be followed for every field in each of the holding numbers. Nasimon and her son ran out of money for lobbying for the compensation, forcing them to give up after receiving a couple of instalments. Whatever money they did get was received in instalments at a rate determined by the land office, which was much lower than the usual market prices. The land office determined the price according to the average price mentioned in the land registration document from that village, which was always lower than the actual price at which lands were bought/sold in practice. Mentioning lower prices in the registration document to evade registration tax payable to the government was a normal practice in the village. Moreover, getting compensation in instalments didn't create enough capital to buy land elsewhere. Money was spent on lobbying the land office and used for other everyday purposes. All of Nasimon's seven sons turned to agricultural labour and the family now belongs to the poor segment of the village.

Stories such as this, that show the impossibility of villagers acquiring compensation for their land and the denial of their rights by the 'formal' procedures, are blowing in the wind of Borogram village in the form of evening chats at the village tea stalls.

Having heard Nasimon's story, local people know what is at stake and how unlikely it is that they will receive adequate compensation, especially those people with Khas land: 'if owner of 'Kagojer jomi' can't claim their rights over their land and get proper compensation how would people living in 'Khas jomi' claim their rights? We just cannot allow mining to take place in our land' (Field notes, May 17, 2009). ${ }^{6}$

Resistance to mining is evident. As Barrington Moore notes, 'what infuriates peasants (and not just peasants) is a new and sudden imposition or demand [...] that is a break with accepted rules (Moore 1979: 474).

\section{'In a new place I will have to live with my head down': Anxiety breaks out}

This section will discuss how local resistance is inspired by some concerns and anxieties of a 'private' nature that often remain unexpressed in public forums of protests in the village. I examine how the lived experiences within social groups, such as the 'Samaj', ${ }^{7}$ and the observed 'good' qualities of the 'community' play a role in forming the resistance to the threat of displacement. Here we see how, whilst framed around 'land' and 'land grab', 
dispossession involves much more than losing property or even livelihoods, it also involves losing community ties and social capital that may have taken generations to build up.

While land, assets, and a house were all noted as quantifiable units by which an amount of money could be fixed as compensation by the impact assessment team of Asia Energy, these also carry other meanings to the people of Borogram in unquantifiable terms. These aspects are not readily open to the 'outsider' surveyor, and are much more complicated than a commodity to be compensated. In the realms of village life, ownership of land represents 'Samman' (respect), which brings people social leadership and pride. A house is more than just a living place; it is a 'home' built upon generational community relations. Displacement from land and house means the loss of 'home' and community. Loss of community means loss of 'Samman' that was earned over years. Previous experiences of migration compound the trepidations of losing a 'home'.

For Borogram people stories of migration are of losing homes, land, 'Samman', 'protipotti' (pride), and the struggle of making a new home. Repeated river erosions resulted in total land loss, forcing migration, and causing homelessness and economic insecurities. The life story of Dewani is one such example:

Dewani was a mobile trader and supplier of ornaments and stones during the 1960s before the independence of Bangladesh. He travelled the entire North Bengal area often for his business and earned enough money to buy over 20 acres of land in his village in Chapainawabgang in North Bengal. His brothers also had a considerable amount of land, some of which was owned hereditarily. He and his brothers enjoyed social leadership and gave final verdicts in mitigating village conflicts. Having gained knowledge about the outside world from his small business, he enjoyed the respect of other villagers.

The River Padma was five kilometres from their village, but it made its way to the village in just a few months. Most of Dewani's agricultural land, including his house, like many others in the village, sunk into the river. In just a few months' time he became homeless with his five children and wife. He moved to his brother's land, which was further away from the river, and built a makeshift house to live in. Having lost almost all of his land, Dewani lost his ability to hire people to work on his land. Hit by river erosions, landless people were desperately looking for work and Dewani was busy looking for additional work outside the village to maintain his family. He was no longer a leader of the village, which had been hit by food and work crises due to the river erosions. People started to move to neighbouring districts in search of work. Many left for cities to pull rickshaws, which was considered disgraceful work. While travelling for his business, Dewani started to look for a place to migrate to, as living on his brother's land was also considered shameful. He chose to migrate to what is now Borogram village. He initially came with 25 other villagers affected by the river. Many others of a similar economic condition followed them in order to build a new village. He left his mother with his brothers in Chapainawabganj, his former village, as she didn't want to move from her home village.

The case of Dewani would be best described as forced displacement, which resulted in a degraded socio-economic status and the loss of the 'forms of social capital' (Wood 2005). The separation from 'home' and land loss implies not only the loss of physical capital but also the loss of social capital such as 'Samman' and these 'lived experiences engender fear [...] and uncertainty' for Dewani (Malkki 1992, 1995). The process that followed was one of regaining his socio-economic position in a new place. Though he left his brothers and 
mother in his former village, a new sense of home was built through a long process that was 'related and intertwined' in forms of collective struggles and cooperation, as well as events of conflicts (Abbas 1994: 442). The people of Borogram migrated from a couple of neighbouring villages in Chapainawabganj; some of these people are known or related to each other, while some are not, but they share the experiences of trauma and rupture of river erosions, which shape the 'collective memories' of displacement in Borogram and add value to the 'new place.'

The hardships of the early days in the 'new' forest land demanded that the people work together and co-operate with each other. People helped each other to clear their pieces of land, as it was impossible to do it alone. Building new houses also required the help of others. Working together helped to bring previously unknown people together to form a society. Visits from forest officials and arrests by the police were regular events which were handled by bribing officials with money raised proportionately from all residents according to the amount of land cleared. Members of the village who were considered clever and/or relatively educated conducted negotiations with officials and were then regarded as 'Dewans', or social leaders.

They also needed to act together in order to guard their crops and cattle from thieves from neighbouring localities, as they were outsiders and thus vulnerable targets. Lacking social connections with other local villages around them, the people of Borogram had to help each other to protect their crops and assets. They formed a group to patrol in the night to prevent thefts and new family relations were built through marriages between families. As the village expanded and the number of people increased, disputes and conflicts within the village also increased. Land disputes, family conflicts, and competition for control of resources, such as irrigation systems, are some examples of the social tensions in Borogram village. To manage the increasing differences between groups, a group of new Dewans were declared by the elderly Dewans to manage conflicts and disputes for their respective clusters of people living in different corners of the village. All these social processes continued to build a feeling of 'samaj' (home, society and societal relations) in Borogram, which were expressed again and again whenever the issues of displacement came up during my stay in the village.

While a house can be built overnight and replaced by another one, a home it cannot be. It is this social and cultural dimension that is inseparable from a sense of home and cannot be compensated in the case of displacement by the development of a mine (Constable 1999). As one village shopkeeper questioned, 'say they will give us a new house [...] but how will they give us our Samaj that we have built here?' (Field notes, March 2, 2009)

More than a home, new social capital built through shared experiences of displacement, struggle over land and cooperation in the 'new place' plays a role in forming the extreme anxiety experienced by the possibility of dislocation by the mining company. Though away from their original home village, this 'new place' brought them what they lost in Chapainawabganj: land and Samaj. It ended the homelessness that was characterised by the disgrace of living on others' land, creating 'new experiences and ways of thinking' (Grundy-Warr and Wong 2000: 93) about the value of Samaj. The early experiences of living in a 'new place' away from the original 'home' accompanied anxieties of being 'new' to the place. Stories are told by the elderly generation of Borogram of how, in the early days, they felt frightened by the neighbouring villagers in cases of conflicts over land, as they were isolated in the 'new place' and did not have much support from other villages. Stories are also common of how muggers from the neighbouring villages kept 
the early residents of Borogram in fear of theft and robbery, as the group was too small to resist and did not have much help from outside the village. These stories influence the way people anticipate the effect of dislocation and the loss of Samaj, as is evidenced by the worries of one Borogram resident, 'If I am displaced to a place where I don't know anyone I will have to live with my head down' (Field notes, 16 May, 2009).

How will I cope with a new place? This question expresses a 'more private, personalized, or idiosyncratic' worry in contrast to public concerns that are discussed and talked about in public (Grundy-Warr \& Wong 2000). The concerns expressed in the previous quotes are of a more public nature and are talked about more openly, while male anxieties about the security of the female members of their family are of a private nature. Living within their own village where people are either related or known to each other for a long time provides a sense of security for the women and girls. In the absence of the male members of the family, relatives or friends next door are there to make the women feel secure. It is common for poor male members of Borogram to work outside of the village and Phulbari town between harvesting seasons when there is a scarcity of work in the village, leaving the women and girls at home. Some go to other districts and towns to work for weeks at a time, leaving their family in the village. Any cases of harassment towards women are dealt with through the Bichar, and the persons responsible are punished verbally, physically, and/or with fines, according to the degree of the harassment. Living in a Samaj provides people with security for the female members of their family and allows them to work outside of the village during crisis periods.

There are other concerns of a private nature that are not expressed explicitly in regular public forums, such as village meetings organised by the national activists. It is only through longer interactions with the people that more subtle concerns are revealed. One aspect of this concerns the informal financial institutions in the village. Access to informal and semi-formal credit facilities is an integral part of village life in Borogram, like elsewhere in Bangladesh (Wood \& Sharif 1997, Sinha \& Matin 1998.). Starting during the 1970s with the innovations of Grameen Bank and its founder Professor Younus, the collateral free village group-based semi-formal small loans and savings facility has become the main financial service system in all of rural Bangladesh. Along with big national social developments, non-governmental organisations and hundreds of small local NGOs provide small credit facilities in the villages. Village solidarity groups are formed to guarantee the repayment of loans taken by any individual and to create peer pressure in cases of default. It is now well established that this system of credit has become extremely popular in all villages in Bangladesh, as is evident by annual reports produced by some of the big players of credit providers (BRAC 2009). Borogram is no exception, with a number of local and national NGOs providing small loans to villagers. However, a closer look at the financial behaviours of Borogram's people reveals a contrasting picture of how and why people in the village, in certain cases, prefer other forms of credit that are more informal in nature and attached to the realms of social relations, despite the presence of numerous credit providers.

Moneylenders still play a role in Borogram's financial market even where NGOs provide credit at a relatively lower interest rate. Sinha and Matin (1998) found that the NGOs are unable to substitute for moneylenders due to their insensitivity to local variations in financial conditions. In Borogram, some aspects of the financial behaviours of poor people are visible to local moneylenders, and are thus better communicated by these lenders than the NGOs. The need for money for the poor in Borogram is related to the 
specificities of the village. As the village is a high land area, its timing and pattern of agricultural production is a little different than that of flat land areas. As we have seen it needs more irrigation than flatter land for rice production in the dry seasons, creating a high demand for loans among the poor during the month prior to irrigation. Since rice production is costly due to extensive irrigation, alternative crops, such as corn, are widely produced in the village. The timing of corn production is different to that of rice production, which is generally the main crop in the area, and so there is a need for loans to meet the cost of production.

41 Maloney (1986) observed some years ago that local moneylenders in Bangladesh have local knowledge about the trends of loans needed in the villages, in addition to the experience of when to provide loans and to ask for the money back. With knowledge about the poor borrowers specific loan needs, local moneylenders provide flexible loans before production and require repayment right after harvesting when people do not mind paying higher interest. In addition, membership in the same Samaj plays the role of collateral for moneylenders and borrowers where default cases are negotiated using longterm social relations. Membership in the Samaj also provides the borrower with the facility of getting a loan without following any fixed procedures and time criteria, which are set by credit organisations during emergency need. Moneylenders often live next door to the borrowers and are related to the borrowers through secondary or tertiary lines of kinship which can be used to convince moneylenders to lend money to people with bad repayment histories. Moreover, it is common in Borogram to repay a loan and interest with the equivalent portion of the crops produced in the land, creating an option for the borrowers who do not want the hassle of going to Phulbari town to sell their crops, or who do not feel confident of getting the proper price for their crops in an unknown town market. They have enough helping hands in the village to weigh their crops properly and give the lender his portion back. Loans often come in kind and take very tiny forms such as a bowl of rice on a day when the main earner is not working due to sickness, or a few eggs to treat relatives making a sudden visit. The entire financial life in the village revolves around a mechanism that is rooted in the qualities of Borogram Samaj. A breakdown of that Samaj poses a particular threat to the poor in need of credit, as one of the poorest farmers in the village noted:

People who have money will buy new land and build new houses in the cities [...] but where will we go... In a new place who will lend us money in an emergency, say, if I need to take my wife to hospital? No one trusts the poor. Here, people know that I will not run away with their money. I can at least ask for some rice from next door when I don't have food in the house. I will at least not die from hunger here... I go to protest meetings regularly (Field notes, August 28, 2009).

Newly developed economic abilities and social statuses, for some, through the acquisition of land in Borogram, also play a role in forming resistance to the possible displacement from mining. A few members of the village acquired large amounts of land, as the result of being early settlers to the village when there was more land available to clear and establish rights to. Possession of such land provided them with the capacity to employ poor villagers to work on their land, thus gaining them a higher social status in the village. Increased economic capacity allowed some to invest money into better institutions in the cities for their children's education thereby further enhancing their social status. One such villager states, 'I might be illiterate but my sons are educated [...] people respect my sons, they come for suggestions and help for different matters. People respect me' (Field notes, 7 July, 2009). This enhanced socio-economic status, which has 
been attained over the years, is now under threat due to the proposed mining; money will not buy the status he has gained. He continues,

I will just be another person in a new place! There would be lot of other people with a lot more money than me. Who would give me so much land in a new place? People won't give a damn if I can't employ a person or two. What will I do with the money? I am not going anywhere from this place [...] they can do whatever they want (Field notes, 7 July, 2009).

What will I do with the money? This question builds on other 'inner' and unexpressed area of disquiet. Bangladesh is a country with more than 80 percent of its total household engaged in agricultural activities (BBS 2008) and numerically dominated by its peasantry (Wood 1976). Historically, agriculture is the main occupation for people in Bangladesh (Barkat et al. 2001) and Borogram is no exception with most of its resident's dependant on generational skills of agriculture for their livelihood. From wage labour to petty landowners, all members invest and re-invest their labour, skills, and money into landrelated production activities. Whatever surplus money is earned from other seasonal occupations, such as short-term migration to the cities, tends to be invested back into the village to better equip themselves, i.e. buying cows to plough the land, for production. Savings accumulated by selling the surplus crops of larger landowners is usually reinvested into buying more land or production equipment, such as an irrigation machine. Small amounts of money accumulated from petty trading in the village market, along with some credit taken from lenders, are used to obtain a piece of land on a fixed yearly or seasonal rent from a neighbour in order to maximize savings by producing cash crops. Money-use patterns revolve around land and production-related activities. Promises by the company and the government for equivalent money for land and assets are received with uneasy anxiety because of people's relative inexperience of using compensation money with good effect in the case of displacement, as is expressed by one participant: 'money doesn't stay in your pocket. A king's treasury would be finished if you can't use it properly. Agriculture is all I know. There is no readymade land waiting for me to be bought. The money they will give me for my assets will go out of pocket quickly' (Field notes, 10 May, 2009). Even when people actually believe that they will get a sum of money for their land and assets, the specific patterns and experiences of money-use which are tied to community relations and based on the land they possess form this denial of the proposals of displacement. These forms of denial are very different to the nationalist framings of the protest and provide a 'more prosaic description' of people's resistance (Baviskar 1995: 213).

\section{Conclusion}

Languages of national interest characterized the protest, organized on a national scale by the activists based in the capital, against land dispossession and mining planned in Phulbari. However, my research, on which this paper is based, shows that local people's concerns are very different.

As this paper has shown, the particular notion of land ownership in Borogram plays a critical role in forming the local resistance against mining. While the local land category of 'Kagojer jomi' is owned through the socially defined 'legal' means, Khas land, on the other hand, is possessed through the presence of the occupier and the value of the long hard work that has been invested in the land to make it cultivable. Rights to Khas land are 
acquired and earned over periods of struggle to protect and nurture the land. The owners of this land find their moral authority to possess the land in the government's declared commitment to landless people.

As the paper also shows, on a more private level, anxieties related to the loss of Samaj, characterised by generational social relations, act to form resistance to the proposal of displacement by the mining development plan. 'Personal and idiosyncratic' aspects of individuals, which are not expressed and talked about openly, such as the male concern for the security of the female members of the family in a new place, enforce the importance of not losing Samaj (Grundy-Warr \& Wong 2000). A particular pattern and timing of crop production in the village presents specific credit needs for the poor which are understood better by relatives or friends in the village who are involved in moneylending.

As Levien (2015) argues, the consequences of dispossession are varied across diverse settings which we must pay attention to. In their own analysis what matters most for the people in Borogram is the protection of their place and accompanying rights. The place produces certain 'social resources' for the individuals in the form of 'kin, status and inclusion in networks, comprising obligations and entitlements' (Wood 2005: 5-6). Any discussion of resistance to land dispossession that fails to recognize these patterns of rights and claims would lack an understanding of the important 'local dynamics' (Ferguson 2006). Understanding local people's analysis could reflect their needs, lived experience and subjectivities that shape the vernacular politics around land.

\section{BIBLIOGRAPHY}

Abbas, Ackbar (1994) 'Building on Disappearance: Hong Kong Architecture and the City', Public Culture, 6(3), pp. 441-59.

Bangladesh Bureau of Statistics (BBS) (2008) Bangladesh Agriculture Census 2008, Statistics Division, Ministry of Planning, Government of Bangladesh, URL: www.bbs.gov.bd/WebTestApplication/ userfiles/.

Bangladesh Bureau of Statistics (BBS) (2001) Bangladesh Population Census 2001, URL:

www.bbs.gov.bd.

Barkat, Abul; Zaman, Shafique-uz; Raihan, Selim (2001) Political Economy of Khas Land in Bangladesh, Dhaka: Association for Land Reform and Development.

Baviskar, Amita (1995) In the Belly of the River: Tribal Conflicts over Development in the Narmada valley, Delhi: Oxford University Press.

Bertocci, Peter (1996) The Politics of Community and Culture in Bangladesh: Selected Essays, Dhaka: Centre for Social Studies.

Cohen, Anthony (ed.) (1985) The Symbolic Construction of Community, New York: Ellis Horwood Ltd.

Constable, Nicole (1999) 'At Home but not at Home: Filipina Narratives of Ambivalent Returns', Cultural Anthropology, 14(2), pp. 203-28. 
Escobar, Arturo; Alvarez, Sonia (1992) 'Introduction: Theory and Protests in Latin America Today', in Arturo Escobar \& Sonia Alvarez (eds), The Making of Social Movements in Latin America: Identity, Strategy, and Democracy, Boulder (Colorado): Westview, pp. 1-40.

Ferguson, James (2006) Global Shadows: Africa in the Neoliberal World Order, Durham (North Carolina): Duke University Press.

Filer, Colin (1990) 'The Bougainville Rebellion, the Mining Industry and the Process of Social Disintegration in Papua New Guinea', Canberra Anthropology, 13(1), pp. 1-39.

Gardner, Katy (1993) ‘Desh-bidesh: Sylheti Images of Home and Away', Man 28(l), pp. 1-15.

Gardner, Katy (1995) Global Migrants, Local Lives: Travel and Transformation in Rural Bangladesh, Oxford: Oxford University Press.

Grundy-Warr, Carl; Wong Siew Yin, Elaine (2002) 'Geographies of Displacement: The Karenni and the Shan Across the Myanmar-Thailand Border', Singapore Journal of Tropical Geography, 23(1), pp. 93-122.

Inden, Ronald (1990) Imagining India, Oxford: Blackwell. Jansen, Erik (1986) Rural Bangladesh: Competition for Scarce Resources, Oslo: Norwegian University Pres.

Kirsch, Stuart (2006) Reverse Anthropology: Indigenous Analysis of Social and Environmental Relations in New Guinea, California: Stanford University Press.

Levien, Michael (2011) 'Rationalising Dispossession: The Land Acquisition and Resettlement Bills', Economic and Political Weekly, 46(11), pp. 66-71.

Levien, Michael (2015), 'From Primitive Accumulation to Regimes of Dispossession: Theses on India's Land Question', Economic and Political Weekly, 50(22), pp. 146-57.

Malkki, Liisa (1992) 'National Geographic: The Rooting of Peoples and the Territorialization of National Identity among Scholars and Refugees', Cultural Anthropology 7(1), pp. 24-44.

Malkki, Liisa (1995) 'Refugees and Exile: From “Refugee Studies” to the National Order of Things', Annual Review of Anthropology, 24, pp. 495-523.

Maloney, Clarence (1986) Behaviour and Poverty in Bangladesh, Dhaka: UPL.

Moore, Barrington (1966) Social Origins of Dictatorship and Democracy: Lord and Peasant in the Making of Modern World, Boston: Beacon press.

Narayan, Deepa (1997) Voices of the Poor: Poverty and Social Capital in Tanzania, Environmentally Sustainable Development Studies and Monographs series 20, Washington, D.C.: The World Bank.

Padel, Felix; Das, Samarendra (2010) Out of this Earth: East Indian Adivasis and the Aluminium Cartel, Hyderabad: Orient BlackSwan.

Perreault, Tom; Valdivia, Gabriela (2010) 'Hydrocarbons, Popular Protest and National Imaginaries: Ecuador and Bolivia in Comparative Context', Geoforum, 41, pp. 689-99.

Sinha, Saurabh; Matin, Imran (1998) 'Informal Credit Transactions of Micro-Credit Borrowers in Rural Bangladesh', IDS Bulletin, 29(4), pp. 66-80.

Tadiar, Neferti (2009) Things Fall Away: Historical Experience and the Makings of Globalization, Durham, NC: Duke University Press.

Tilly, Charles (1985) 'Models and Realities of Popular Collective Action', Social Research, 52(4), pp. 717-47. 
Wood, Geoffrey (1976) ‘The Political Process in Bangladesh: A Research Note', in M. Ameerul Huq (ed.), Exploitation and the Rural Poor, Comillla: Bangladesh Academy for Rural Development, pp. 1-15.

Wood, Geoffrey (2005) 'Poverty, Capabilities and Perverse Social Capital: The Antidote to Sen and Putnam?', in I. A. Khan \& J. Seeley (eds.), Making a Living: The Livelihoods of the Rural Poor in Bangladesh, Dhaka: UPL.

Wood, Geoffrey \& Sharif, Iffath (eds.) (1997) Who Needs Credit? Poverty and Finance in Bangladesh, London: Zed Books Ltd.

\section{NOTES}

1. Police and Bangladesh Rifles (BDR). BDR is a paramilitary force mainly involved in guarding the borders of the country.

2. GCM resources plc (GCM) operated under its former name Asia Energy plc. Asia Energy Corporation (Bangladesh) Pty now operates as a wholly-owned subsidiary of London-based GCM resources plc.

3. Similar demands were made in numerous newspaper articles, for example, Shomakal (2008), 18 December.

4. An elderly Dewani (social leader) who took the initiative to first establish Borogram village.

5. Local landowner.

6. Karim in Borogram village, 'owner' of two acres of Khas land.

7. Bertocci (1996) described Samaj in rural Bangladesh as a mutual social group which is based on reciprocal obligations that 'act[s] out what is morally and ritually meaningful as a communityreinforcing when necessary the normative standards to which all are supposed to adhere' (p. 17).

\section{ABSTRACTS}

This paper argues for a more context-specific understanding of dynamics of resistance to land dispossession in Bangladesh. The context is Borogram, a village in Phulbari where a large scale land appropriation has been planned for a proposed mining project. Emotion against possible displacement from land runs high in Phulbari. Whilst national resistance to mining involved ideas of nationalism and imperialism, local people's experience was different. The paper shows how the stories of resistance to land appropriation need to be understood in relation to social relationships and accompanying entitlements, claims and mutual obligations which exist around a place. The paper argues that dispossession is not merely about the loss of farming land for those threatened by it, but the social ties they have built up over generations in their village.

\section{INDEX}

Keywords: displacement, resistance, Phulbari, land rights, compensation, Bangladesh 


\section{AUTHOR}

\section{SADID NUREMOWLA}

PhD in Social Anthropology (University of Sussex, UK), Adjunct Faculty, Department of Social Sciences and Humanities, Independent University Bangladesh (IUB) 